\title{
The Role of School Management Team in Managing Students' Academic Performance in Community Secondary Schools in Tabora Municipality- Tanzania
}

\author{
Mabula Jonas, Demetria Gerald Mkulu
}

Department of Educational Foundation, St. Augustine University of Tanzania, P.O.BOX 307, Mwanza

Received: 02 Dec 2021; Received in revised form: 19 Jan 2022; Accepted: 27 Jan 2022

(C)2022 The Author(s). Published by TheShillonga. This is an open access article under the CC BY license

(https://creativecommons.org/licenses/by/4.0/)

\begin{abstract}
This study aimed at examining the role of school management team in managing students' academic performance in Tabora municipality Tanzania. The study employed mixed method approach and convergent parallel design to collect data. The study involved both qualitative and quantitative data. The study applied simple random sampling technique and purposive technique to collect information from respondents. Simple random sampling technique was used to select community secondary schools, teachers and students while purposive sampling technique was applied to sample heads of secondary schools and district education officer to participate in the study. The study employed questionnaires and interview guides to collect information from respondents. Questionnaires were applied to collect information from teachers and students while interview guides were used to collect data from heads of schools and District Educational Officer. Quantitative data were analyzed by using statistical package of social science (SPSS) version 20 while thematic analysis was used to analyze qualitative data. The findings revealed that school management team plays a great role in managing the performance of students academically. Furthermore, the findings of the study revealed that school management team is facing various challenges such as lack of training to members of SMT, insufficient support from community around the school, students' misbehaviors, inadequate of financial support from the government, unconduicive of teaching and learning environment, lack of teaching and learning materials and lack of parents' involvement in students learning process. The study suggests that the government should provide enough funds to the school management team in community secondary schools to enable them be able to manage students' academic performance.
\end{abstract}

Keywords - School, Management Team, Students, Academic Performance, Community Secondary Schools.

I. INTRODUCTION AND BACKGROUND TO THE STUDY

Education which is viewed as a social institution serving the needs of society has been considered as an essential tool for sustainable development of the society that flourishes from one generation to another (Paschal and Mkulu, 2020) ;( Daniel, 2017). However, the existence of quality education of any society is affected by the existence of several factors such as cooperative learning in the classroom as well as teacher- students' relationship in the school contexts. (Paschal, Nyoni, and Mkulu, (2020). In spite of the mentioned factors seemed to be critical; the school management team (SMT) is among of the most prominent factors in school which has the power to influence whichever in positive or negative ways, students' achievement. SMT is made up of principal, deputy principal and heads of departments depends on the size of the school (Maja, 2016). Principal's duties are to communicate with staff members to ensure that everything is done accordingly (Daniel, 2017) ; (Mulai, 2011). The principal also has other duties such as planning for school development, organizing, directing, implementing and communicating with school governing board members about all activities taking place at school. (Daniel, 2017). In order to have effective teaching, learning and quality education school management team should work properly so that the workers perform their duties and roles as required. From this light, (MOEVT, 2010); Nkwana (2010) have noted that School management team is very important tool in managing, controlling and evaluating the whole process of teaching and learning. For example, school management team is responsible to ensure that students' academic performance is achieved because it plays a number of roles in encouraging the students to 
work effectively and efficiently towards acquiring academic performance as well as life skills.

In England and North Ireland State schools are managed by school governing boards which have the mandate to supervise all activities that take place at school on academic matters (Sulley, 2016). The school governing boards are the ones responsible for school administration, strategic planning, staff appointment and dismissal of workers who are not fulfilling their duties, school accountability and staff appraising. The public secondary schools are operating by boards which are known as school governing boards (SGB). These boards have been given all authorities to control each and every thing that takes place in all government secondary schools. In South Africa the schools are supervised by school management teams which started to be used in 1996 by the Act 84 of 1996. The Act gave the mandate of planning, directing, supervising and controlling school activities to the school management team. This Act set the base structure of managing schools in the whole country (Daniel, 2017). The school management teams were given the power to control the day to day activities at schools.

In Kenya management of education at all levels is managed by different organs. For instance Mulai (2011) point out that, school management committee (SMC) and Centre Management Committee (CMC) are used to supervise primary schools while Board of Governors (BOG) is used to manage secondary schools and tertiary institutions. All these organs are used in order to ensure that teachers perform their duties well so that students can be able to get better performance at the end of their studying period. In Tanzania SMT is made up of school head, deputy school head, academic master, and school accountant and discipline master (MOEVT, 2010); Nkwana (2010) . The school management team has several duties and roles such as; implementation of education and training policy, planning for school development, directing and controlling school budgets, managing day to day affairs of school, ensuring high quality for new constructions and school maintenance, to ensure a conducive teaching and learning environment including putting sports and games in school timetable, supervising and ensuring high quality of teaching and learning including effective use of time on tasks for the entire school day (Ministry of education and vocational training,2010).

The role of SMT is to plan, implement and make evaluation of teaching and learning process at school. Tabora municipality is among the districts in Tanzania where secondary schools do not perform well in form four national examinations despite the fact that most of schools have school management teams which are responsible for planning, implementing, controlling and making evaluation of every activity done at school as directed by ministry of education (MOEVT, 2010). For instance some schools in Tabora municipality have been performing poor for the last five years consecutively from 2016 to 2020.For instance in 2020 some secondary schools in Tabora municipality performed very poor in form four national examination and some of them ranked last positions regional wide. Therefore the current study was intended to find out the role played by school management team to ensure that students' academic performance is improve in Tabora municipality.

\section{STATEMENT OF THE PROBLEM}

Tanzania has experienced an alarming increase in the number of students failing in community secondary schools since its independence (Paschal and Mkulu, 2020). Despite the fact that the government and the ministry of education has made a number of reforms in the system of education such as improvement of curriculum, construction of infrastructure and hiring of new teachers in community secondary schools, the issue of poor students' academic performance continues to be a big challenge in community secondary schools in Tanzania (Nghambi (2014); Kambambovu (2018); (Paschal and Mkulu, 2020); In relation to that, most of the researches in Tanzania are done to assess the factors that contribute to the massive failure of students within public secondary schools. The majority focus on assessing learning materials and the environment than looking at how school management team can affect the academic performance of the students. The majority of community secondary schools in Tabora municipality are among of the schools in Taboraregion which perform poor in national examinations especially in form four examinations (NECTA, 2020); (Tanzania Ministry of education and vocational training (2010). For example in 2020 form four national examination, some community secondary schools in Tabora municipality performed very poor and some of them ranked in last positions regional wide (NECTA, 2020). This situation has been taking place for several years. It is in this regard the current study was intended to investigate the role played by school management team in managing students' academic performance in community secondary schools in Tabora municipality with the hope that the study will bring a perspective to how school management team affects academic performance in community schools in Tabora, Tanzania 


\section{General Objective}

To examine the role of school management team in managing students' academic performance in community secondary schools. The current study was guided by three objectives.

i. To find out managerial functions of school management team in managing students' academic performance in community secondary schools.

ii. To examine the contribution of school management team in managing students' academic performance in community secondary schools.

iii. To determine challenges facing school management team in managing students' academic performance in community secondary schools.

\section{Research Questions}

i. What are managerial functions of school management team in managing students' academic performance in community secondary schools?

ii. What is the contribution of school management team in managing students' academic performance in community secondary schools? iii. What are the challenges facing school management team in managing students' academic performance in community secondary schools?

\section{Significance of the Study}

This study aimed at finding out the role of school management team in managing students' academic performance in community secondary schools in Tabora municipality. Therefore the final results of this study is sought to provide the wide knowledge to students, teachers and parents about the importance of school management team. It will also guide policymakers and curriculum designers to involve school management team in policy making and curriculum preparation in order to ensure that students' academic performance is improved. In addition the study will help the government to understand the challenges facing school management team in dealing with educational challenges hindering students' academic performance. Moreover this study will help school management team in their daily activities of supervising the whole process of teaching and learning to ensure the effectiveness of teaching profession in order to improve students' academic performance.

\section{Conceptual Framework}

\begin{tabular}{|c|c|c|}
\hline $\begin{array}{l}\text { Independent Variables } \\
\text { Planning } \\
\text { Organizing } \\
\text { Directing } \\
\text { Managing } \\
\text { Controlling } \\
\text { Implementing } \\
\text { Evaluating }\end{array}$ & $\begin{array}{l}\text { Intervening Variables } \\
\qquad \begin{array}{l}\text { Government support } \\
\text { Political } \\
\text { interference }\end{array}\end{array}$ & $\begin{array}{l}\text { Dependent Variables } \\
\text { Students' } \\
\text { academic } \\
\text { performance. } \\
\text { Discipline for } \\
\text { students } \\
\text { Team work }\end{array}$ \\
\hline
\end{tabular}

Fig.1.1 Conceptual Frame Work

Conceptual frame work is a diagrammatic representation of concepts of variables that show the interconnections between the independent, intervening and dependent variables (Mburu, 2016). Independent variable is the variable which affects another variable positively or negatively. In this study the independent variables are functions of school management team which included planning, organizing, directing, managing, controlling implementing and evaluating while dependent variables included students' academic performance, discipline for students, team work and teaching professional improvement. Intervening variables included government support and political interference. If the functions of school management team would be performed well, they would influence students' academic performance, discipline for students, teamwork and teaching 
professional improvement. The government support and political interference are very important to school management team members in fulfilling their duties. It is the role of school management team to apply its efforts to ensure that these managerial functions are performed in a proper way in order to achieve goal.

\section{LITERATURE REVIEW}

\section{Theoretical Review}

This study was guided by administrative management theory which was profounder by Henry Fayol in 1916 in German Jengo (2016). The theory shows the importance of dividing the tasks among workers according to their specialization. In addition, Daniel (2017) Italso suggests that there should be job specialization in an organization like school since it helps workers to perform their duties efficiently and effectively (Uzugbu and Nnadozie (2016). In addition, Daniel (2017) point out that school without job specialization cannot perform better the duties. School management team has the responsibility to ensure that all activities are done accordingly by considering teachers' specialization. This theory is applicable to the current study and is useful to it since it shows how different duties and responsibilities in the organization like school should be carried out so as to improve the performance of students in a particular school. However, the theory has some weakness as it depends much on managers' skills in order to make more efficiency in an organization. Nevertheless the administrative theory enables organization to achieve the goal if it is applied properly.

\section{Empirical Review}

\section{Managerial Functions of School Management Team in Managing Students' Academic Performance.}

School management team should perform different functions in order to manage students' academic performance; these functions include control students' discipline, involving parents in students' learning process and improving teaching and learning environment. The study conducted by Watson and Sanders (2012) in USA about the understanding of parental participation in American public education, revealed that parental involvement in student' studying was very crucial since it creates corporation that allows greater collaboration between home and school environment to improve students' outcomes. In addition, parental involvement in education was seen important because it added value to educational development of students of all ages. However, Hanover Research (2019) in Southern Dakota of United States of America observed that factors like effective teachers, providing academic, social and emotional supports to students, to influence students 'performance. In addition the findings revealed that teachers are the most impactful of all school based factors but not the most important factor overall. This implies that the teachers can help students to perform well in their studies but he/she needs the support or readiness of the students and the out of school based factors to fulfill that intention since the students can be affected by external factors such as parents, conflicts and family poverty that can hinder the students' performance. Communication is another factor that influences students' academic performance. The study done by Nkwana (2010) about the responsibility of Educators and SMT on curriculum implementation, delivery and intervention in South Africa revealed that, communication is among the factors influencing students' academic performance at school. Through communication members of school management team are able to communicate the school mission, vision and objectives that the school aims to achieve. Nkwana maintains that, to implement the curriculum depends much on the extent to which teachers are informed and prepared. This implies that the proper way of implementing the curriculum to meet the objectives and goals that have been set by the school there must be effective communication between School Management Team members, teaching staff and non-teaching staff.

Also Rasebotsa (2017) argued that, proper communication increases the quality of relationship and simplifies the implantation of curriculum development. The organization that needs to grow well it must use effective communication in order to strengthen the relationship among employees and employers of that organization. Therefore in order to perform school activities accordingly there should be well communication channels that will help to pass information from school leaders and their subordinates. This will simplify the process of teaching and learning to take place at school.

Moreover, Wambui (2018) examined the influence of girls' perceptions and attitude towards mathematics in secondary schools of west lands district in Kenya. The study found out that the school good performance depends on good teachers, motivation and the typical leadership style used at a certain school. This implies that the quality of school depends on the quality of teachers who are working at that school. In some developing countries the factor of education of teacher is the most important element of determining the quality of education being provided. School management team has the role to monitor and evaluate the whole process of teaching and learning of every individual teacher in order to improve teacher's profession. 
Furthermore Kambambovu (2018) investigated the influence of school leadership on students achievement at Rombo district in Tanzania and the findings indicated that, school leadership is the factor which influences students' academic performance since leadership at school is very important in order to ensure that everything done at school is done accordingly. He maintained that leadership is the manner in which school leaders are proving directions, orders, and implementing schools plans so as to obtain the desired goals and objectives. The aim of the current study is to investigate how SMT manage leadership style as one of the factors that influences student's academic performance so as to enable teaching and learning process to take place at school.

\section{The Contribution of School Management Team in Managing Students' Academic Performance.}

The school management team contributes much in managing students academic performance by fulfilling different functions like supervising the whole process of teaching and learning, approving school budget, managing students discipline and solvating different problems happening at the work so that the student academic performance at schools.

The study conducted in USA by Watson (2012) commended that when school management encourages parental involvement in students' learning process; it creates a partnership between home and school which improves students' academic performance. In addition the study showed that when parents participate in their children's' learning it increases the commitment of students to the studies which helps them to perform well in the examinations. Therefore involvement of parents in education is very crucial since it improves educational development of students of all ages. The study shows the importance of parents to be involved in all matters concerning students' learning process.

Also, Nnangwa (2013) conducted a study in Abia state in Nigeria to find out the role of school management team in the process of education reforms. The findings revealed that school management team has a great role in ensuring good leadership by choosing the proper leadership style that helps to influence students' academic performance. In addition the study also showed that leadership style is very important to ensure that learning and teaching process takes place at school to facilitate the achievement of school goal which is to ensure high academic achievement of students in their studies

In the same line, Ntseto (2015) asserts that school management team contributes much to ensure that all supportive services are provided to teachers within a clear and well organized plan action. This implies that the SMT should ensure that everything needed for implementation of curriculum and policies that are brought to school by the government has been provided to enable teaching and learning process to take place smoothly at school. In order to meet this role SMT should communicate with other educational officers and other stakeholders. Moreover Daniel (2017) conducted a study in South Africa about the role of SMT in curriculum management.The findings revealed that the school management team plays a great role to ensure the daily professional management of the school. The study also shows thatthe functions of school management team are to plan, implement, organize, control and assess the whole process of students' learning at school. In addition, the study emphasized that the implementation of curriculum at school is done under the supervision of SMT. The study also reveals the importance of making school evaluation to check whether the planned programmes are done in the manner that enables the achievement of the school goal and objectives.

Moreover, Booysen (2010) found out that schools in South Africa were performing poor because there was no school evaluation done to see how the process of teaching and learning was carried out. This implies that evaluation in any institution has great significance since it aims at making the improvement in the organization.

Furthermore, MOEVT (2010)put out the roles and duties of school management team which include implementation of education and training policy, preparing school development plans and school budgets, managing daily activities of school, ensuring high quality for new constructions and school maintenance, to ensure a conducive teaching and learning environment including integrating of sports and games in school timetable, planning, supervising and controlling all school activities taking place at school. This implies that school management team has been given duties and roles to plan, implement and evaluate all activities carried out at school to ensure that students' academic is well achieved.

Challenges Facing School Management Team in Managing Students' Academic Performance.

The school management team encounters several challenges in fulfilling its duties. These challenges become an obstacle to SMT in managing the performance of students. For instance, Kapur (2018) conducted the study in India about the factors lead to students' academic performance in secondary schools. The findings revealed that factors like family poverty, parents illiteracy, large family size, lack of provision of tuitions or extra classes, inadequacy of resources, lack of planning programmes, lack of interests in studies, psychological factor family conflicts and disputes, fear of examinations and lack of 
motivation to students are among factors that hinder the student better performance in the examinations

UNESCO (2011) suggests that the big number of students enrolled lead to inadequate of resources and has resulted into difficulties in creating the expected outcomes .This has made school management to be more complex and difficulty enterprise than few decades ago. This implies that, due to the increase number of students' enrolment which does not match with the available resources in community secondary schools school management team fail to provide the requirements that needed for teaching and learning process to be carried properly. Hence leads to students' failure in academic performance. Lack of school heads' commitment is among the factors that hinder the students' academic performance. UNESCO (2011) maintains that performance of students in community secondary schools cannot be achieved in schools where school heads are not in fully committed to play their roles effectively and efficiently. This implies that school heads commitment has great impact on students' performance.

Also, Atchia and Chinapah (2019) conducted a study in Mauritius about the factors affecting students' academic performance on secondary school students' .The results revealed that $90.1 \%$ of students' academic achievement can be affected by school leadership, students' socioeconomic factors and teacher. This indicates that school leadership style, students' economic status and teacher can hinder the better performance of the student

In addition, the study done by $\operatorname{Mestry}(2017)$ in south Africa about assisting principals to lead and manage public schools effectively found out that, school management team members have a heavy work load and sometime do not have time to perform their instructional management functions .The findings also showed that Members of school management team have other duties out of administrative duties like teaching subjects heads of different departments like academic department.

Not only that but also, Kithinji (2013) conducted a study in Kenya to examine the administrative challenges facing school management and school heads that can affect academic achievement of students in day secondary schools. The findings showed that students' indiscipline, shortage of teaching and learning materials and school physical facilities are among the challenges that facing school management in ensuring the academic performance of students.

Similarly, Masenyi (2014) also examined the factors that lead to students' poor performance in English subject in secondary schools in Magu district in Tanzania. The study employed descriptive survey research design in data collection. The findings showed that factors like insufficient number of teaching and learning materials, lack of enough number of teachers, lack of motivation to teachers and poor attitudes of teachers and students contribute much on students' poor academic achievements. The study also found out that students lack competence in English language because they lack support from parents and the whole community in which they live. Therefore failure in English language leads to the failure in other subjects because in secondary schools all subjects except Swahili subject are taught in English. Hence, understanding English language becomes the base for understanding other subjects.

Moreover, Nghambi (2014) conducted a study in Tabora about the factors hindering students' academicperformance in certificate of secondary education examination in community secondary school. The findings showed that poor performance in form four examination was caused by several factors like poor working environment for teachers, poor supply of teaching and learning materials, high teacher student ratio which is one teacher to 65 students and poor teaching methodology. The study also emphasized that many students in community secondary schools are not ready to carry out their duties in studying. Moreover the study showed that most of students go to schools as a fashion or they have been forced by laws that need every child to go to school. Some of these students see school like a contact area where they can meet with their friends and peer groups and chat. School management team is responsible to eliminate truancy at school since it is among the factors hinder students' academic performance at school. Furthermore, the study done in Tabora municipality by Kambambovu(2018) about leadership styles in relation to students' academic performance revealed that, leadership styles applied by school management is among the main factors hindering students' academic achievement in community secondary schools in Tabora municipality.

\section{Knowledge Gap}

Most of the reviewed studies showed that, school management team is very important in improving students' academic performance at school. The studies also showed that school management team plays a great role in supervising the daily activities done at school in order to enable students to perform well. Most of the reviewed studies were done out of Tanzania like (Ntseto 2015; Booysen 2010; Daniel 2017; Kithinji 2013; Mulai 2011; Mburu 2016and Nkwana 2010) and few were done and documented in Tanzania like (Nghambi 2014; Kambambovu 2018; David 2014 and Jengo 2016) .

However most of these studies done in Tanzania focused much on factors affecting students' academic performance 
like(Nghambi 2014; Jengo 2016 and Kambambovu 2018) Not only that but also some of the reviewed studies used pure qualitative approach to collect data like (Maja 2016 and Ntseto 2015).Moreover most of these reviewed studies have long time like (Ntseto2015; Booysen 2010; Kithinji 2013; Mulai 2011; Mburu 2016;Nkwana 2010 and Nghambi 2014; Maja 2016; Masenyi 2011; Nkwana2010 Nnangwa 2013;David 2014). This shows that there is the missing gap which needs to be filled. It is in this regard the researcher found out that there is a need to conduct this study on the role of school management team in managing students' academic performance in Tabora municipality so as that the gap can be filled.

\section{RESEARCH METHODOLOGY}

This study employed mixed research approach; which enabled collection of data which have qualitative and quantitative features (Mugenda, 2003). The researcher adopted convergent parallel design which involved collecting both quantitative and qualitative data simultaneously (Creswell, 2014; Oso and Onen, 2016). The target population of this study comprised of students, teachers, heads of secondary schools and district education officer in Tabora municipality. Simple random sampling was used to select students and teaching staff, while purposive sampling was used to select heads of schools and district education officer. The study employed a sample size of 186 respondents ((Mugenda, 2003).

Data was collected using questionnaires and interview guide. Questionnaires were used to collect data from students and teachers; while interview guide was used to collect data from heads of schools and from district education officer. Validity of the research instrument was checked by different research expertise, while reliability was checked using split half technique (Mugenda and Mugenda, 2003; Tracy, 2013). Qualitative and quantitative data was collected simultaneously. The researcher analyzed quantitative data using a statistical package for social science (SPSS) version 20 and the data are presented using tables, graphs and explanations. Again, quantitative data were analyzed using thematic analysis and the researcher presented these data using explanation and the use of quotations from the respondents (Oso and Onen, 2016)

The study adhered to several ethical principles in research like seeking permission letter, privacy and confidentiality, anonymity, informed consent, avoiding plagiarism as well as avoiding physical and psychological harm to the respondents.

\section{RESULTS AND DISCUSSION OF THE FINDINGS}

\section{Presence of School Management Team in Secondary Schools}

The question was constructed in order to know the presence of SMT in secondary schools in Tabora municipality. The figure below shows the teachers' responses about the presence of SMT.

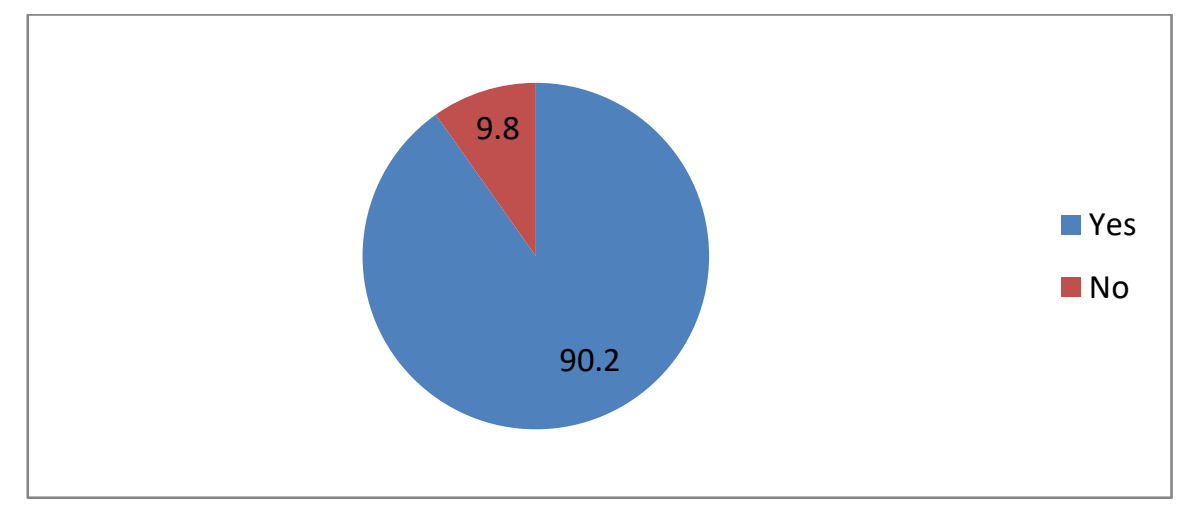

Fig.4.1. Teacher's responses on the presence of SMT in secondary schools $(n=82)$

Source: Field Data, (2021)

The findings in figure 4.1 indicated that 90.2 percent of respondents said that their schools have a school management team, while only 9.8 of respondents said that their schools have no SMT. This implies that in Tabora municipality the community secondary schools have school management teams which supervise the schools' daily activities. The presence of SMTs in community secondary schools in Tabora municipality was also proved through the interview with interviewee 2 , who said that, 
Our school has school management team which controls each and every thing done here at school such as preparing school time table, controlling students' discipline, preparing school budget, organizing and supervising internal tests and examinations and preparing school plan for the whole year (Interviewee 2, October 12, 2021).

This issue was also addressed to students, and their responses are presented in figure 4.2

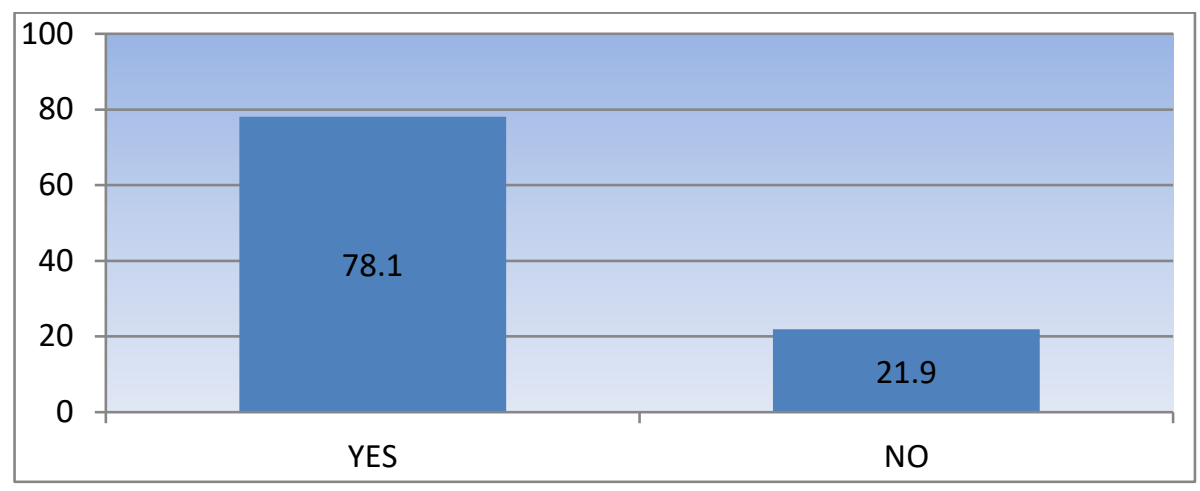

Fig.4.2 Students' responses on the presence of SMT in secondary schools (n-96)

Source: Field Data, (2021)

The findings in figure 4.2 indicated that 78.1 percent of respondents agreed that there is school management team at their schools while 21.9 percent of respondents said that their schools have no SMT. This result shows that even students are aware of the presence of school management team in their schools. One interviewee was quoted commenting that;

All community secondary schools have school management teams which supervise all activities done at schools. Under the supervision of school heads, SMTs ensure the following at school: proper utilization of teaching and learning resources, controlling school discipline, preparing schools short and long plans, implementing school plans, Preparing school budget, and organizing internal and joint examinations (Interviewee 1, October 12, 2021).

\section{Understanding of Managerial Functions of SMT}

The researcher was very interested to know if the students know the managerial functions of SMT. The question was set for students and their responses were presented on figure 4.3 below

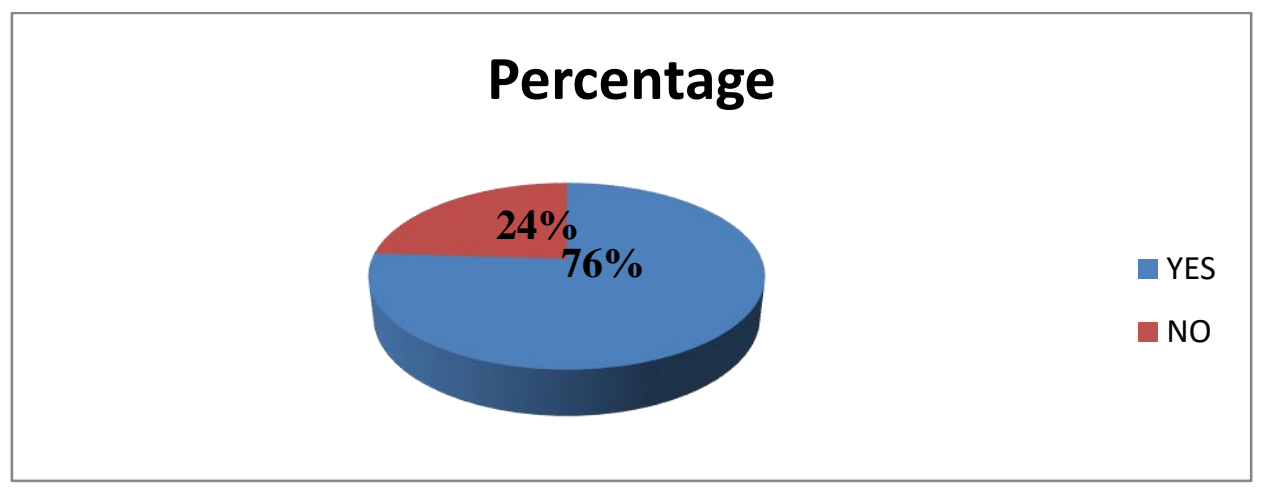

Fig.4.3 Students' responses about the understanding of managerial functions of SMT ( $n=96)$

Source: Field Data, (2021)

The findings in figure 4.3 indicated that 76 percent of students agreed that they understand managerial functions of SMT while only 24 of students said that they do not understand the managerial functions of SMT. The findings show that the majority of students understand the managerial functions of school management team (SMT) in supervising the daily activities. The understanding of managerial functions by students helps both SMTs members and students to increase their efforts to ensure that the school predetermined goals are achieved through 
cooperation between students, teachers and school management team members.
The question was also addressed to teachers and their responses are open in figure 4.4

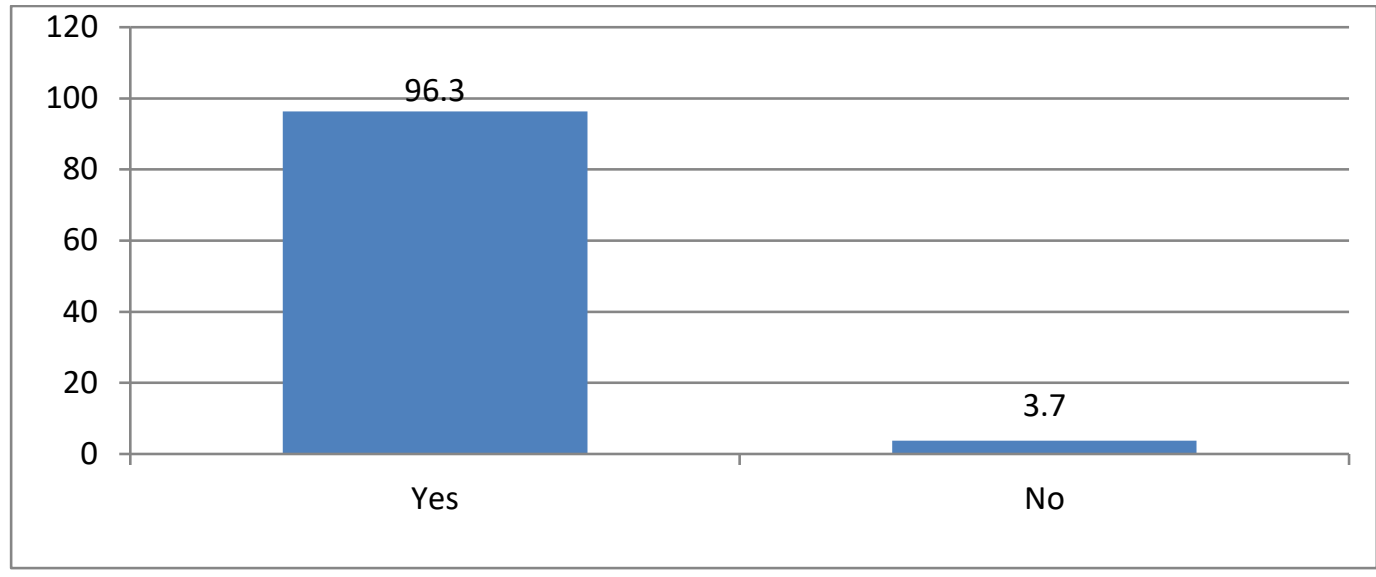

Fig.4.4 Teachers' responses about the understanding of managerial functions of SMT $(N=82)$

Source: Field Data, (2021)

The findings in figure 4.4 indicate that 96.2 percent of teachers know managerial functions of SMT while 3.7 percent of teachers said that they do not know the function of SMT. This findings showed that teachers in Tabora municipality know the functions of school management team at their schools. The findings imply that in Tabora municipality the majority of teachers have a great understanding of the roles played by their SMTs in ensuring that the students' academic performance is improved .

Through open-ended questionnaires teachers were asked to mention and explain some Managerial functions of school management team and the responses from teachers are presented on table 4.1 below;

Table 4.1 Managerial Functions of School Management Team Mentioned by Teachers $(n=82)$

\begin{tabular}{llll}
\hline NO & ITEMS & FREQ & Percentages \\
\hline $\mathbf{1}$ & Maintaining students discipline & 29 & 45.4 \\
$\mathbf{2}$ & Solving problems & 16 & 19.8 \\
$\mathbf{3}$ & Motivating teachers and students & 15 & 17.5 \\
$\mathbf{4}$ & To encourage cooperation among teachers & 14 & 17.3 \\
& & & \\
& Total & $\mathbf{8 2}$ & $\mathbf{1 0 0}$ \\
\hline
\end{tabular}

Source: Field Data, (2021)

The findings in table 4.1 indicate the managerial functions of SMT mentionedby teachers. It was discovered that 45.4 percent mentioned to maintain students' discipline, 19.8 mentioned that SMT is responsible for solving several problems in schools, 17.5 percent pointed out that it is responsible for motivating teachers and students and 17.3 percent commented that it is responsible for encouraging cooperation among teachers

This result was explored more in an interview where one interviewee has maintained that;

School management team has a lot of tasks to perform; among of them is to make sure that every student has acceptable discipline. We believe that if students have discipline, other school activities including teaching and learning process can be done in a smooth way (Interviewee 4, October 12, 2021).

It was also discovered that even students are aware of the functions of school management team. Through open-ended questionnaires, students have explained the functions presented in table 4.2 
Table 4.2 Managerial functions of School Management Team mentioned by students $(N=96)$

\begin{tabular}{llcc}
\hline NO & ITEMS & FREQ & Percentages \\
\hline $\mathbf{1}$ & To manage students' academic performance & 19 & 15.9 \\
$\mathbf{2}$ & To manage students discipline & 29 & 35.8 \\
$\mathbf{3}$ & To control teaching and learning process & 27 & 33.8 \\
$\mathbf{4}$ & To improve learning environment & 21 & 27.5 \\
& Total & 96 & 100 \\
\hline
\end{tabular}

Source: Field Data, (2021)

The findings in table 4.2 indicate that 15.9 percent of students have claimed that SMT has a duty to manage students' academic performance, 35.8 explained that they have a role to manage students discipline, 33.8 percent to control teaching and learning process and 27.5 percent mentioned to improve learning environment. Moreover the managerial functions of SMT was also demonstrated by the interviewee 3 who said,

Some of the core managerial functions of SMT are, to ensure school discipline, planning for school development, supervising proper utilization of resources, and supervision of teaching and learning process (Interviewee 3, October 12, 2021).
The findings are in line with administrative theory which suggests that the institution should have regulations and rules which will help to guide workers on how to perform their duties effectively in order to ensure the provision of quality products (Edward, 2018). This implies that teachers have to abide to the code of conducts of teaching profession to ensure that everything done at school is done accordingly.

\section{Contribution of SMT in Managing Students' Academic Performance.}

The researcher wanted to check the understanding of students on the contribution of SMT on students' academic performance. The students' responses are presented on figure 4.5 as follows:

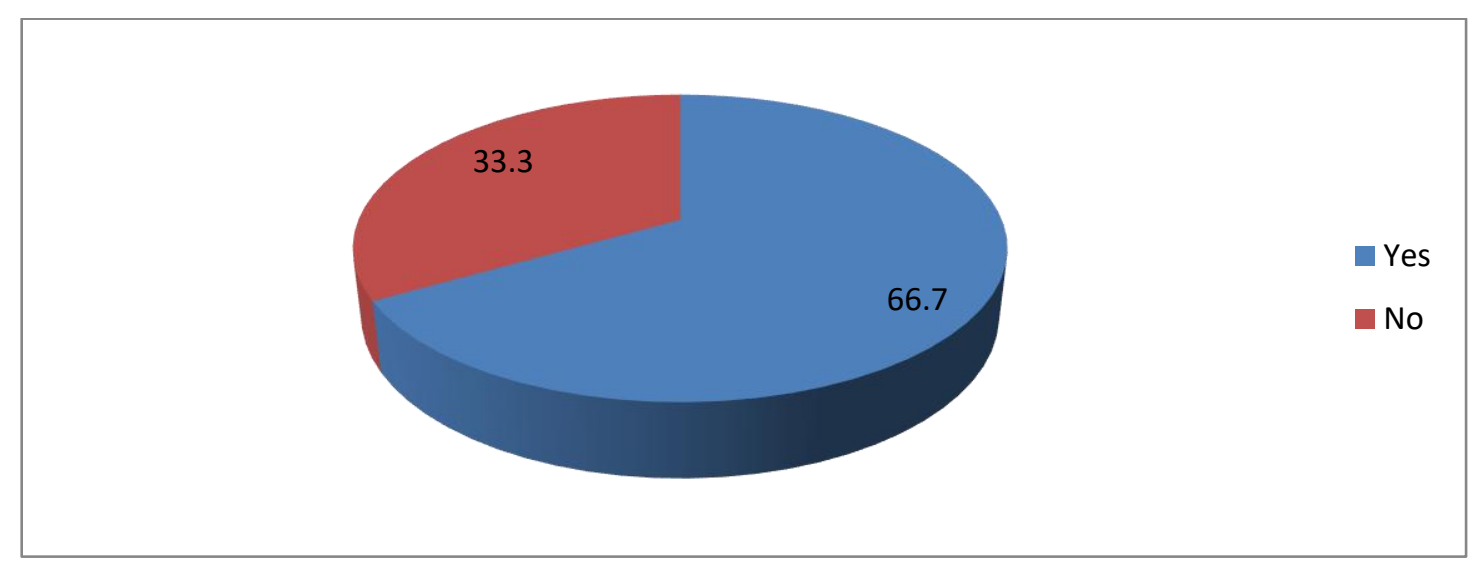

Fig.4.5 Students' responses on the contribution of SMT in managing students' academic performance.( $n=96)$

Source: Field Data, (2021)

The findings in figure 4.5 shows that 66.7 percent of students agreed that SMT has a contribution in managing students' academic performance while 333.3 percent of students disagreed that SMT contributes to students' academic performance. The findings found out that the majority of students know the contribution of SMT in managing students' academic performance in Tabora. In addition, the same theme emerged in the interview with interviewee 3 who stated that,
The contribution of SMT in improving students' performance is very high in our schools because the team has a duty of controlling students' discipline, organizing examinations, and ensuring provision of teaching materials (Interviewee 3, October 12, 2021). 
On this issue, teachers' responses are presented in figure

4.6

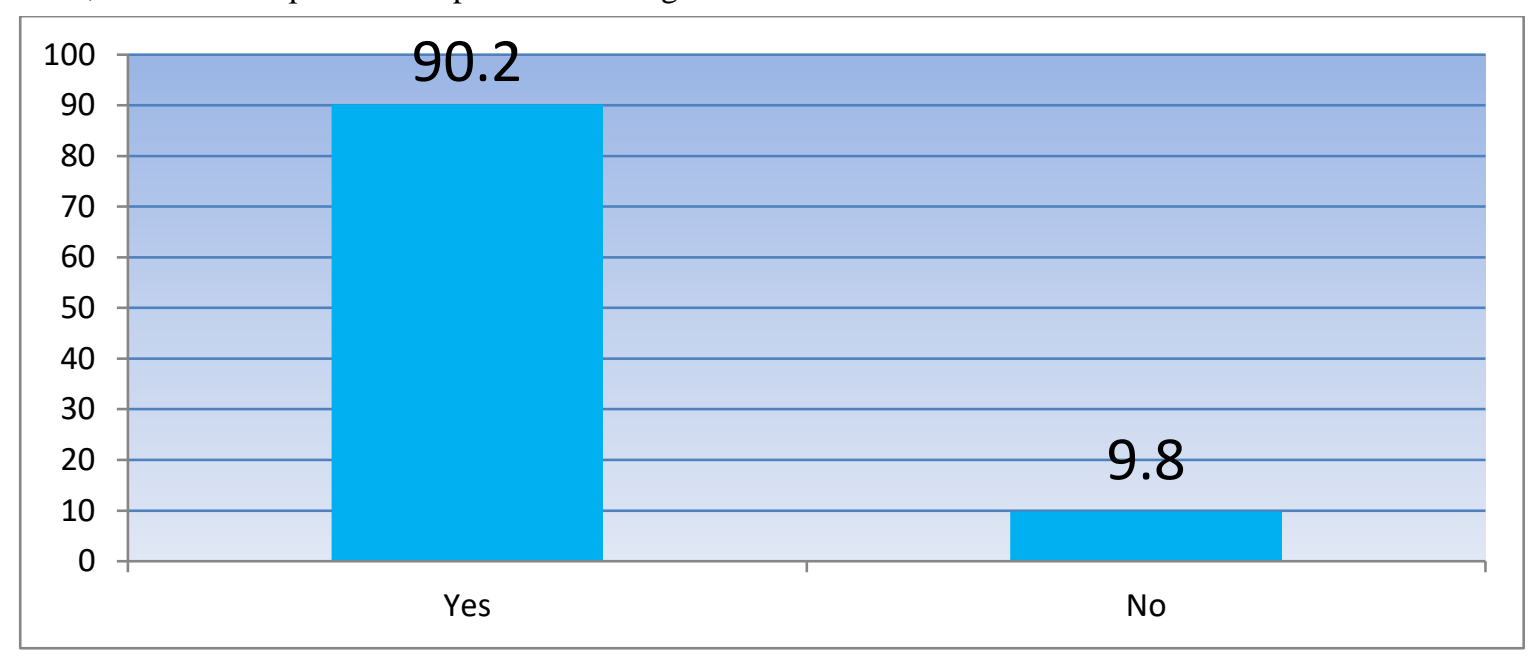

Fig.4.6 Teachers' responses on the contribution of SMT in managing students' academic performance $(n=82)$

Source: Field Data, (2021)

The findings in figure 4.6 indicated that 96.3percent of teachers agreed that SMT contributes in managing students' academic performance while 3.7 percent of teachers did not agree that SMT has a contribution on students' academic performance. The findings found out that the majority of teachers are familiar with the contribution of SMT in managing students' academic performance. In an interview, it was also established that SMT has a great contribution to the students' academic performance through their duties including supervising the teaching and learning process.

In addition, the findings were in line with Kambambovu (2018) who revealed that the school management team

Key: 1 = Strongly Disagree, 2 = Disagree, $3=$ Neutral, 4 = Agree, $5=$ Strongly Agree

Table 4.3 Students' Responses on the Challenges Facing SMT In Managing Students' Academic Performance ( $n=96)$

\begin{tabular}{|c|c|c|c|c|c|c|c|c|c|c|c|}
\hline No & Challenges & 1 & & 2 & & 3 & & 4 & & 5 & \\
\hline & & $\mathbf{F}$ & $\mathbf{P}$ & $\mathbf{F}$ & $\mathbf{P}$ & $\mathbf{F}$ & $\mathbf{P}$ & $\mathbf{F}$ & $\mathbf{P}$ & $\mathbf{F}$ & $\mathbf{P}$ \\
\hline 1 & There is lack of Financial support. & 18 & 18.8 & 14 & 14.6 & 19 & 19.7 & 36 & 37.5 & 9 & 9.4 \\
\hline 2 & $\begin{array}{l}\text { Students' commitment to the studies is very } \\
\text { low }\end{array}$ & 9 & 9.4 & 14 & 14.6 & 20 & 20.8 & 35 & 36.5 & 18 & 18.8 \\
\hline 3 & $\begin{array}{l}\text { School management team members are not } \\
\text { trained regularly. }\end{array}$ & 7 & 7.3 & 14 & 14.6 & 34 & 35.4 & 25 & 26 & 16 & 16.7 \\
\hline 4 & There is lack of support from parents & 22 & 22.9 & 15 & 15.6 & 20 & 20.8 & 26 & 27.1 & 13 & 13.5 \\
\hline
\end{tabular}

Source: Field Data, (2021)

The findings in table 4.3 indicates the students' responses as follows: 46.9 percent of students agreed that lack of financial support to the school management team is a challenge, 33.4 percent did not agree and 19.7 percent of plays a great role in influencing students' academic performance. This is because they participate in supervising all activities performed at the schools. For instance it is responsible to ensure that teachers are attending their periods as indicated on school time table.

\section{Challenges Facing SMT in Managing Students' Academic Performance.}

The researcher was interested to know the challenges that face SMT in fulfilling its duties to improve students' academic performance. The findings from the students are presented on table 4.3 below. 
Financial support is very important as it helps the SMT to perform well its duties. This was supported by interviewee 3, who said;

The school management team tries its level best in planning for school development including improving the process of teaching and learning but sometimes our plans remain unimplemented due to the fact that there is no enough funds to implement the plans (Interviewee 3, October 12, 2021).

Moreover, the findings in table 4.3 shows that 58.3 percent of students have agreed that student's low commitment to their studies is a challenge to the performance of SMT in managing students' academic performance, 14.6 percent disagreed with the statement. The findings show that majority of students in Tabora municipality agreed that low commitment to studies is among the challenge facing school management team in managing students' academic performance. Interviewee 3 has also maintained that;

Our students are not committed to their studies; and I find that some of them come to school because they are forced by their parents or guardians and others come to school as a fashion but they are not concentrating well in their studies (Interviewee 3, 12, October, 2021)

The findings concur with Kpolovie (2014) who examined the student's interest in studying and academic performance. The scholar has discovered that the students' interests in learning are very low; something that become an obstacle to the SMT in managing the academic performance of students.

Again, the findings in table 4.3 indicates that 42.7 percent of students have agreed that lack of regularly trainings to members of school management team is a problem that facing SMT in managing students' academic performance, while 21.9 percent disagreed with the statement. Interviewee 4 has also commented that there is no regular training given to those teachers appointed to be members of SMT to equip them with knowledge and skills (Interviewee 4, October 12, 2021).

The findings are in line with Jengo (2016) who has also discovered that among the big challenge that face school management team is the lack of training to the members. This shows that training to SMT is very important in improving students' academic performance in community secondary schools.

Also, the findings in table 4.3 indicated that 40.6 percent of students agreed that lack of support from parents is a challenge that facing SMT in managing students' academic performance, while 38.6 percent disagreed with the statement. The findings revealed that the majority of respondents agreed that lack of parents' participation in students learning is a great challenges to SMT.

This was supported the interviewee 4 who said,

The big challenge that our school faces is inadequate support of parents in students learning. Some parents think that their role is to buy uniforms and exercise books to their children only and the process of guiding students is the work of teachers who have been trained to do so. Some parents do not come to school even when they are asked by the teachers to do so (Interviewee 4, October 12, 2021).

The findings concur with Watson (2012) who revealed that parental participation in students learning plays a great role in improving students' academic performance. This indicated that parents' involvement in teaching and learning process is very important in ensuring the best student's academic performance.

On the same issue, the responses from Teachers are presented in table 4.4

Table 4.4 Teachers Responses on the Challenges facing SMT in managing students' academic performance( $n=82)$

Key: 1 = Strongly Disagree, 2 = Disagree, $3=$ Neutral, $4=$ Agree, $5=$ Strongly Agree

\begin{tabular}{lllllllllllll}
\hline No & Challenges & 1 & & 2 & & 3 & & 4 & & 5 \\
\hline & & $\mathbf{F}$ & $\mathbf{P}$ & $\mathbf{F}$ & $\mathbf{P}$ & $\mathbf{F}$ & $\mathbf{P}$ & $\mathbf{F}$ & $\mathbf{P}$ & $\mathbf{F}$ & $\mathbf{P}$ \\
1 & There is lack of Financial support. & 4 & 4.9 & 12 & 14.6 & 27 & 32.9 & 24 & 29.3 & 15 & 18.3 \\
2 & $\begin{array}{l}\text { Students' commitment to the studies is very } \\
\text { low }\end{array}$ & 8 & 9.8 & 4 & 4.9 & 26 & 31.7 & 30 & 36.6 & 14 & 17.1 \\
3 & $\begin{array}{l}\text { School management team members are not } \\
\text { trained regularly. }\end{array}$ & 2 & 2.4 & 9 & 11 & 23 & 28 & 26 & 31.7 & 22 & 26.8 \\
& & & & & & & & & & & &
\end{tabular}


Source: Field Data, (2021)

The findings in table 4.4 indicates that 47.6 percent of teachers agreed that lack of financial support is a big problem to school management team in managing students' academic performance, while 19.5 percent disagreed with the statement. The findings revealed that the majority of teachers in community secondary schools agreed that lack of financial support is the challenge to the students' academic performance. This was also demonstrated through the conversation with interviewee 4 who said

Among the challenges which face our SMT is lack of enough funds that can enable us to implement all school plans that we have planned to do. The school management team have a lot of plans but due to financial challenge, some of the plans are not fulfilled (Interviewee 4, Oct. 2021).

Financial support to SMT helps to motivate them so that they can increase their creativity and innovation in teaching process which improves students' academic performance. This is supported by administrative theory which suggested that, workers have to be creative and innovative in order to increase the output, which must go hand in hand with financial support (Uzuegbu, 2015)

The findings in table 4.4 indicate that 53.6 percent of teachers agreed that students low commitment to their studies is a challenge that facing SMT in its daily activities, while 14.7 percent disagreed with the statement. The findings show that the majority of teachers in Tabora municipality agreed that low commitment to studies is among the challenges facing school management team in managing students' academic performance. Masenyi (2014) has suggested that lack of motivation to students leads to poor attitudes in learning. Therefore, students need to be reinforced to study, which must go hand in hand by ensuring that they get all what they are supposed to get to learn effectively.

The findings in table 4.4 indicate lack of regular trainings to the members of school management team is the problem that hinders SMT in managing students' academic

Table 4.5 Students' suggestions to SMT in managing students' academic performance $(n=96)$

\begin{tabular}{llll}
\hline NO & ITEMS & FREQ & Percentages \\
\hline $\mathbf{1}$ & Increasing teaching and learning resources & 35 & 40.2 \\
$\mathbf{2}$ & Time for remedial should be reduced & 16 & 13.3 \\
$\mathbf{3}$ & To provide food to students & 24 & 24.8 \\
$\mathbf{4}$ & To reduce punishment to students & 21 & 21.7
\end{tabular}

performance. In this, 58.6 percent of teachers agreed with the statement, while 13.4 percent disagreed. The findings indicated that the majority of teachers' in Tabora municipality agreed that lack of regular trainings to members of school management team leads to poor performance of the team in managing students' academic performance.

Also, table 4.4 presents a statement that lack of parental support to the students learning process is a challenge which hinder the SMT to manage the academic performance of students. It is indicated that 61.0 percent of teachers agreed with the statement, while 14.6 percent disagreed. The findings found out that the majority of teachers in Tabora municipality agreed that lack of parents' involvement in students' learning is a hindrance to students' academic performance. One interviewee has claimed that;

Parents do not give us support
effectively in dealing with students'
discipline. When we work closely to
control their children's behavior,
some of them think that we hate their
children and this is really
discouraging (Interviewee 3, October
12, 2021)

On this issue, Ramalepe (2015) has pointed out that educational administrators should create the conducive environment where teachers, students and parents treat each other with respect in order to participate well in the process of teaching and learning. This means that the students' academic performance can be simply achieved if teachers, students and parents work together.

\section{Suggestions of the Participants to School Management Team}

The researcher was interested to know the suggestions of respondents to SMT in managing students' academic performance. The students' results are presented in tables 4.5 
Total

96

100

Source: Field Data, (2021)

The findings in table 4.5 shows that 40.2 percent of students has suggested that teaching and learning resources must be increased, 13..3 explained that time for remedial should be reduced, 24.8 suggested that food must be provided to students, and 21.7 percent have pointed out that punishment to students must be reduced.

Table 4.6 Teachers' suggestions to SMT in managing students' academic performance $(n=82)$

\begin{tabular}{llll}
\hline NO & ITEMS & FREQ & Percentages \\
\hline $\mathbf{1}$ & To increase cooperation among teachers & 28 & 34.2 \\
$\mathbf{2}$ & To solve all school problems & 20 & 24.5 \\
$\mathbf{3}$ & To motivate students and teachers & 16 & 18.4 \\
$\mathbf{4}$ & Provision of punishment to students who misbehave & 18 & 23.9 \\
& Total & 82 & 100 \\
\hline
\end{tabular}

Source: Field Data, (2021)

The findings in table 4.6 indicated 34.2 percent of students have claimed that cooperation among teachers must be increased, 24.5 explained that school problems must be solved effectively, 18.4 have commented that teachers and students must be motivated to work hard and also 23.9 percent elaborated that all students who misbehave must be punished. For example, interviewee number 5 has suggested that,

The school management team should be strong enough to effectively play its role in managing students' academic performance. For instance it should be able to control students and teachers discipline and monitoring each and every thing taking place at school (Interviewee 5, October 12, 2021)
The findings concur with UNESCO (2011) which observed that students cannot perform better in community secondary schools if there is no strong school leadership which is able to fulfill its duties effectively and efficiently. In order to improve students' performance leaders should be able to carry out their responsibilities as required. This also concurs with the School Management Theory which suggests that school management team should have authority to give directions and orders about what should be done in teaching and learning process (Uzuegbu, 2015)

The researcher was interested to know the suggestion of the respondents to the government on how it can support the SMT to manage students' academic performance effectively. The responses from teachers are presented in table 4.11 below.

Table 4.7 Teachers' suggestions to the government $(n=82)$

\begin{tabular}{llll}
\hline NO & ITEMS & FREQ & Percentages \\
\hline $\mathbf{1}$ & Provision of in service training to teachers about school management & 25 & 31.6 \\
$\mathbf{2}$ & Improving salaries to teachers & 20 & 22.4 \\
$\mathbf{3}$ & Increasing financial support to run school activities & 14 & 17.5 \\
$\mathbf{4}$ & Providing teaching and learning materials & 23 & 28.5 \\
& Total & 82 & 100
\end{tabular}

Source: Field Data, (2021)

The findings in table 4.7 present teachers' suggestions to the government. It was discovered that 31.6 percent of teachers have suggested that the government should provide in service training to teachers, 22.4 suggested that teachers' salary must be improved, 17.5 suggested that increasing financial support to SMT is the best strategy, and also 28.5 percent have suggested that the government 
should provide enough teaching and learning materials. Interviewee number 2 said that,

Provision of management skills to the SMT, and increasing capitation grants to the community schools will help SMT to perform its duties well. students, involving the community around the school and organizing joint examinations are some of the strategies to improve students' academic performance (Interviewee 2, October 12, 2021)

Again, motivating teachers and

Table 4.8 Students' suggestions to the government ( $n=96)$

\begin{tabular}{llll}
\hline NO & ITEMS & FREQ & Percentages \\
\hline $\mathbf{1}$ & To build enough classrooms & 28 & 29.9 \\
$\mathbf{2}$ & To provide financial support to SMT & 32 & 33 \\
$\mathbf{3}$ & To increase teachers' salaries & 17 & 17.5 \\
$\mathbf{4}$ & To provide in service training to teachers & 19 & 19.6 \\
& Total & 96 & 100 \\
\hline
\end{tabular}

Source: Field Data, (2021)

The findings in table 4.8 indicated the suggestions of student's to the government as follows. 29.9 have suggested that the government of Tanzania should finance the construction of enough classrooms, 33 percent commented that providing financial support to SMT could be the best strategy, 17.5 percent suggested that teachers' salary should be modified, and also 19.6 percent have suggested that the government should ensure provision of in service training to teachers. In this, interviewee number 4 suggested that,

In order to solve the challenges facing SMT, the government of Tanzania should provide all the needed supports in community secondary schools like building classes, laboratories, toilets, teacher's houses, to improve teachers' salary and bringing in the learning resources (Interviewee 4, October 12, 2021).

The findings were also in line with the school management theory which emphasizes that the salaries to the workers should be satisfactory to meet workers' needs because it helps to motivate teachers to perform their duties efficiently. Again the theory emphasizes that the workers should work in conducive environment (Uzuegbu, 2015)

\section{CONCLUSIONS AND RECOMMENDATIONS}

Basing on the first objective the study concluded that, teachers and students' have great understanding about managerial functions of SMT therefore they should be involved in everything SMT plans in order to simplify implementation of the plans. Regarding on the second objective the study concluded that, school management team has great contribution in managing students' academic performance therefore it should be supported by community, parents and government in order to fulfill its duties effectively.Referring to the third and last objective the study concluded that, School Management Team encounters many challenges in fulfilling its duties in managing students' academic performance.

Basing on the findings obtained the study generally included that school management team is very important in ensuring students' academic performance not only in Tabora municipality but also in all secondary school in Tanzania. Therefore it should be given support by all education stakeholders so that it may be able to fulfill its responsibilities effectively and efficiently.

\section{RECOMMENDATIONS}

Basing on the findings of this study he following recommendations were made.

I. Teachers should be given seminars after being appointed to be members of school management team to make them be familiar with school management skills.

II. In service training has to be provided to all teachers so as to make them have up to date skills of teaching.

III. Policy makers should involve school management team in policy making so as to simplify the implementation of their policies. 
IV. The curriculum developers have to include school management team in developing and changing curriculum to simplify the process of curriculum implementation.

V. The government should employ more teachers so as to decrease the problem of shortage of teachers especially science teachers.

VI. The community around the school should participate well in students learning process so as to improve the students' performance.

VII. The school management team should encourage parents' participation in students' learning process so as to guide students be committed to the studies.

VIII. The government and the community should participate in building classrooms to all community secondary schools.

IX. The government should increase teachers' salaries in order to motivate them to perform their duties efficiently.

$X$. School management team should supervise the utilization of the available resources used in teaching and learning.

XI. The school management team should encourage cooperation among teachers in order to build the spirit of team work at working places.

\section{SUGGESTIONS FOR FURTHER STUDIES}

I. New study to be conducted about the role of SMT in private secondary schools.

II. The research to be conducted on the role of SMT in boarding secondary schools.

III. The study to be conducted on the role of SMT on teachers' job performance in community secondary schools.

\section{REFERENCES}

[1] Atchia, C.M\& Chinapah, V. (2019). Factors affecting academic achievement on secondary school students in Mauritary. Journal of Education and Research.9(1), 70 - 90.

[2] Booysen, C. (2020). The role of school management team in translating school evaluation into school development: a case study of a school in the Western Cape University. (Master dissertation, Western Cape University)

[3] Creswell, J.W. (2014). Research Design Quantitative, Qualitative and Mix methods Approaches ( $4^{\text {thed}}$ ).English Language Teaching, 12(5), $40-41$

[4] Daniel, N. L. (2017). A case study: The role of school management team in curriculum Management (Master Dissertation, University of KwaZulu-Natal).

[5] David, M. N. (2014). Determinants of poor academic performance of secondary students in Sumbawanga district
Tanzania. (Master dissertation, Sokoine University of Agriculture Morogoro Tanzania).

[6] Edward, R. (2018). An elaboration of administrative theory of 14 principles of management by Henry Fayol. International journal for empirical education and research 1(1) $41-41$.

[7] Edward, A.J, Ismail, N. and Kinchin, G. (2017).Pilot study does it really matter? Learning lessons from conducting a pilot study for a qualitative $\mathrm{PhD}$ Thesis. International Journal of Social Science Research 6(1), 1 - 17.

[8] Hanover Research. (2019). Factors influencing students learning. ULEAD Education South Dakota state University.

[9] Jengo, L. S. (2016). School management in community secondary schools in Rombo district: Effects on the students' academic performance. (Master Dissertation, Open university of Tanzania).

[10] Kambambovu, M.E. (2018). Assessment of leadership styles in relation to students' academic performance in secondary school: A case of Tabora municipality. (Master Dissertation, Open University of Tanzania).

[11] Kithinji, F. N. (2013). Headmaster's administrative challenges that affects academic performance of day secondary school in Igoji East institution of Meru Country, Kenya (Master Dissertation, Kenyatta University).

[12] Maja, T.S. A. (2016). School management team members understanding of their duties according to the personnel administration measures. (Master Dissertation University of Pretoria).

[13] Masenyi, F. J. (2014). Factors associated with students' poor performance of English language subject in secondary schools: A case of Magu district council.(Master Dissertation, University of Dodoma, Tanzania)

[14] Mburu, C. D . (2016). Influence of selected factors on academic performance of secondary schools students in Kuresoi Sub-County, Nakuru County, Kenya. (Master Dissertation, University of Egerton).

[15] Mestry, R. (2017). Empowering principals to lead and manage public schools effectively in the 21 Century South African. Journal of Education, 37(1), 1 - 16.

[16] Ministry of Education. (2010). Guidance for quality assurance and standards assessment of school in Kenya. Nairobi, Kenya: Government Printer

[17] MoEVT. (2010).Education development plan: Education sector development programme.

[18] Mugenda, G. A. (2003).Research methods: Quantitative and qualitative approaches. Nairobi, Kenya: ACTS.

[19] Mulai, M.E. (2011). Roles of boards of governors in the management of secondary schools in Kasikeudivision, Nzaui district.(Master dissertation, Kenyatta University).

[20] NECTA. (2016). Certificate of secondary education examination results enquires from www.tanzania.go.tz.

[21] NECTA. (2017). Certificate of secondary education examination results enquires from www.tanzania.go.tz.

[22] NECTA. (2018). Certificate of secondary education examination results enquires from www.tanzania.go.tz.

[23] NECTA. (2019). Certificate of secondary education examination results enquires from www.tanzania.go.tz. 
[24] NECTA. (2020). Certificate of secondary education examination results enquires from www.tanzania.go.tz.

[25] Nghambi, C. H. (2014).Factors contributing to poor academic performance in certificate of secondary education examination for community secondary schools in Urambo district of Tabora Tanzania. (Master dissertation, Open University of Tanzania).

[26] Nkwana, S. M. (2010). Their response of educators and school management team members on curriculum delivery intervention programmes. (Master Dissertation University of Pretoria, VedfromPsuEdu).

[27] Nnangwa, K. (2013). Role of school managements on school performance. European Scientific Journal, 2(1), 2136.

[28] Ntseto, M. R. (2015). The role of school management teams in rendering learning support in public primary schools. (Masters Dissertation University of Free State).

[29] Oso, Y.W \& Onen. (2016). A general guide to writing research proposal and report: A hand book of beginning researchers. Nairobi, Kenya: Jomo Kenyatta Foundation Enterprise Road, Industrial Area.

[30] Paschal, M. J.\& Mkulu, D. G. (2020).Teacher- students' relationship and students 'academic performance in public secondary schools in Magu District, Tanzania. Journal of Research in Education and Society, 11(1), 20-31

[31] Paschal, M. J., Nyoni. T. T. \&Mkulu, D. G. (2020). The role of cooperative learning in attaining inclusive learning in the classroom, creativity and innovation in secondary schools in Mwanza region, Tanzania. International Journal of English Literature and Social Sciences,(IJELS),5(2), 364 - 373.

[32] Ramalepe, L.M. (2015). The role of school management team in cultivating moral purpose in Limpopo secondary schools. Mediterranean Journal of social sciences, 6(2) $2039-2117$

[33] Rasebotsa, D. (2017). How curriculum advisor and school management team communicate curriculum changes in schools: (Masters Dissertation, University of Pretoria).

[34] Sulley, D. J.(2016). Challenges faced by school boards in managing community secondary schools: The case of Kiteto district Manyara region Tanzania. (Master Dissertation, University of Dodoma).

[35] Tracy, S. J. (2013).Qualitative research methods: Collecting evidence, crafting analysis, communicating impact. John Willey \& Sons.

[36] UNESCO. (2011). Better school: resources materials for school (leads in African (introductory modules a usews guide. unit one) from library "unesco Cba.Org/ English/Better-Schools.

[37] Uzuegbu, P. C. \& Nnadozie, O.C. (2015). Henry Fayol's 14 principles of management: Implications for libraries and information centers. Journal of Information Science Theory and Practice. 3(2), $58-72$.

[38] Wambui, K. M. (2018).Factors influencing girls' perceptions and attitude towards mathematics in secondary schools of west lands districts, Nairobi County, (Masters Dissertation, Kenyatta University).

[39] Watson, G. L. \& Sanders, L. E. R. (2012). Understanding of parental involvement in American public education
.International Journal of Humanities and Social Science, 2(19), 41-50. 